\title{
SECURITIZATION AS AN INSTRUMENT OF ADMINISTRATION OF TERRITORIAL SELF-GOVERNMENT UNITS' FINANCES
}

\section{The financial policy of territorial self-government units}

The administration of assets by self-government units is one of their most important activities. This activity refers to financing of all the fixed and current assets as well as financing the needs of the members of a particular self-government community. In order to make appropriate decisions about the administration of assets, a self-government unit has to make use of instruments such as shaping strategies for financing assets, administering debts within limits defined in Articles 169 and 170 of the Act of 30 June 2005 on Public Finance ${ }^{1}$ (Public Finance Act 2005), predicting debts and monitoring the costs of debts ${ }^{2}$.

The activities of self-government units, including decision-making within the financial policy, entail a certain group of risks. Among the risks in the self-government activity, six basic types of risk can be distinguished. These risks include operational risk, financial risk, risk of damages and assets loss, political risk, social risk and investment risk ${ }^{3}$. For the financial security of the self-government's tasks being carried out, the financial risk is particularly important. The effects of miscalculating the financial risk may burden self-government budgets for many years to come. The financial risk is directly connected with the operational risk (associated with the

1 The Act of 30 June 2005 on Public Finance (Journal of Laws - Dz. U. No. 249, item 2104 with amendments).

2 M. Dylewski, Zarządzanie kapitałem i długiem, [in:] M. Dylewski, B. Filipiak, M. Gorzałczyńska-Koczkodaj, Finanse samorządowe. Narzędzia. Decyzje. Procesy, Warsaw 2006, p. 175. Vide: M. Dylewski, Prognoza długu publicznego jako prawny i ekonomiczny instrument oddziaływania na długoterminowe decyzje w jednostkach samorządu terytorialnego, [in:] Sanacja finansów publicznych w Polsce, edited by K. Święch and A. Zalcewicz, Szczecin 2005, p. 323-336; B. Filipiak, M. Dylewski, Prognoza długu publicznego w jednostkach samorządu terytorialnego, "Finanse Komunalne" 2005, no. 11, p. 23-36.

3 B. Filipiak, Rodzaje decyzji finansowych a ryzyko, [in:] M. Dylewski, B. Filipiak, M. Gorzałczyńska-Koczkodaj, Finanse samorządowe..., p. 107. 
administration of public funds when carrying out current tasks) as well as the risk of investment (associated with long-term investments) ${ }^{4}$.

There are several ways to limit the risk in the activity of territorial selfgovernment units which is an element of the administration of assets. These are, among other things, a choice of financial instruments that balance one another in terms of risk, transfer of risk, and diversification of sources of financing. The basic financial instruments used by territorial self-government units to finance a budget deficit and debt, as defined in Article 168 Section 2 of the Public Finance Act, are credits, loans and municipal securities 5 . These instruments, however, are burdened with a high financial risk.

An instrument that allows to transfer risk from the originator to investors is securitization ${ }^{6}$. This means that the financial risk (as well as other risks that a territorial self-government unit takes carrying out its tasks) is transferred from the territorial self-government unit originating securitization into an SPV (special purpose vehicle - a participator in the process of securitization which issues securities) and the investors that buy the securities backed with the assets transferred.

Bearing the above in mind, securitization of certain self-government assets appears to be an interesting and convenient financial instrument used by selfgovernments to conduct their financial policies. It should be taken into account, however, that securitization used as an instrument which brings self-governments external means to be paid for and repaid is also burdened with a group of risks such as, e.g., market risk (including the risk of fluctuations in interest rates or in exchange rates), risk of reinvestment, operational risk, liquidity risk, and legal risk (e.g. a possibility of legal flaws in contracts concerning the transfer of claims or subparticipation, which can even cause investors' regress from the originator) ${ }^{7}$.

It needs to be underlined that the decision about securitization to be carried out by territorial self-government units should be preceded by a thorough analysis of not only the financial but also the social costs and benefits.

4 M. Dylewski, Identyfikacja ryzyka finansowego w JST, [in:] Bankowo-finansowa obsługa jednostek samorządu terytorialnego, edited by B. Filipiak and S. Flejterski, Warsaw 2008, p. 211.

5 J. Sierak, Zasady i formy pozyskiwania przychodów zwrotnych przez jednostki samorządu terytorialnego, [in:] Gospodarka finansowa jednostek samorządu terytorialnego w warunkach decentralizacji zarządzania sektorem publicznym, edited by H. Sochacka-Krysiak, Warsaw 2008, p. 200-207.

6 B. Półtorak, Ryzyko w transakcji sekurytyzacji aktywów bankowych, "Prawo Bankowe" 2004, no. 10, p. 68.

7 Ibidem, p. 62-63. 


\section{The notion of securitization}

Securitization is currently one of the most dynamically developing financial instruments ${ }^{8}$ used to administer the financial liquidity and the assets liquidity as well as to administer the assets themselves ${ }^{9}$. At the same time, securitization is one of the most complicated forms of gaining capital on international markets ${ }^{10}$, which is shown by the fact that not only experts on banking but also auditors, solicitors, tax and financial advisors participate in conducting securitizations ${ }^{11}$. The development of securitization is determined by such processes as globalization, internationalization and market deregulation, or simply by growing knowledge and, consequently, by growing needs ${ }^{12}$.

In the last years the principles of securitization in the EU have been unified. This fact should contribute to further development of this financial technique in Europe. At present, in the EU securitization is regulated by Directive $2006 / 48 / \mathrm{EC}^{13}$ and Directive 2006/49/EC ${ }^{14}$. These Directives result from the amendments to the two previously binding directives, i.e. Directive 2000/12/EC ${ }^{15}$ (the Consolidated Banking Directive - CBD) and Directive 93/6/EEC ${ }^{16}$ (the Capital Adequacy Directive), introduced by the Capital Requirements Directive (CRD $)^{17}$. The CRD is an instrument that is used to implement Basel II in the legal systems of the EU and its member states. Its contents were devised and proposed by Basel Committee on Banking Supervision ${ }^{18}$.

Securitization is a process whereby instruments of the credit market are introduced into the capital market, which means issuing securities backed with specified packages of assets called asset-backed securities ${ }^{19}$. In other words, securitization is a form of gaining capital by, e.g. territorial self-government units, their unions as well as by, e.g. enterprises or financial institutions, whereby the assets owned by a particular subject are converted into securities which are then sold on

8 (edt.), Dwa miliardy złotych do funduszy sekurytyzacyjnych, "Biuletyn Bankowy" 2006, no. 4, p. 23.

9 J. Koleśnik, M. Rewieński, Sekurytyzacja wierzytelności bankowych - wybrane aspekty, "Prawo Bankowe" 2000, no. 7-8, p. 81; J. Grodzicki, R.W. Kaszubski, Sekurytyzacja - aspekty prawne, "Glosa” 1999, no. 8, p. 4.

10 J. Węcławski, Sekurytyzacja - nowa forma finansowania przedsiębiorstw, "Bank i Kredyt" 1994, no. 8, p. 49.

11 Ł. Reksa, Sekurytyzacja po polsku, "Bank" 2003, no. 10, p. 51.

12 Ibidem, p. 51.

13 Directive 2006/48/EC of the European Parliament and of the Council of 14 June 2006 relating to the taking up and pursuit of the business of credit institutions (OJ L 177, 30.6.2006).

14 Directive 2006/49/EC of the European Parliament and of the Council of 14 June 2006 on the capital adequacy of investment firms and credit institutions (OJ L 177, 30.6.2006).

15 Directive 2000/12/EC of the European Parliament and of the Council of 20 March 2000 relating to the taking up and pursuit of the business of credit institutions (OJ L 126, 26.5.2000).

16 Council Directive 93/6/EEC of 15 March 1993 on the capital adequacy of investments firms and credit institutions (OJ L 141, 11.6.1993).

17 J. Zombirt, Mamy ja!, "Bank" 2005, no. 10, p. 22-23.

18 More about Basel II: Konsultacje i wdrożenie postanowień Nowej Umowy Kapitałowej w sektorze bankowym w Polsce, "Prawo Bankowe" 2005, no. 7-8 (supplement), J. Zombirt, Nowa Umowa Kapitałowa. Ewolucja czy rewolucja, Warsaw 2007.

19 J. Zombirt, Polubić sekurytyzację, "Bank" 1998, no. 5, p. 35. 
the financial market. Securitization is also defined as a process of 're-packing' of a group of claims, e.g. tax or credit claims, and other groups of relatively non-liquid assets into a form of securities, providing that they have some common qualities.

As defined in Article 4 Subparagraph 36 of the CBD, 'securitization' means a transaction or scheme, whereby the credit risk associated with an exposure or pool of exposures is tranched, having the following characteristics:

- payments in the transaction or scheme are dependent upon the performance of the exposure or pool of exposures; and

- the subordination of tranches determines the distribution of losses during the ongoing life of the transaction or scheme.

During the development of securitization instruments, initially 'traditional securitization' was used. Along with the development of the derivatives market, a new form of securitization called 'synthetic securitization' was introduced. The CBD defines both types of securitization. As defined in Article 4 Subparagraph 37 of the CBD, 'traditional securitization' means a securitization involving the economic transfer of the exposures being securitized to a securitization special purpose vehicle which issues securities. This shall be accomplished by the transfer of ownership of the securitized exposures from the originator credit institution or through subparticipation. The securities issued do not represent payment obligations of the originator credit institution. As defined in Article 4 Subparagraph 37 of the CBD, 'synthetic securitization' means a securitization where the tranching is achieved by the use of credit derivatives or guarantees, and the pool of exposures is not removed from the balance sheet of the originator credit institution.

On the whole, securitization can be characterized as a process which involves the following elements ${ }^{20}$ :

- selecting homogeneous assets from the whole portfolio of assets (the originator of securitization selects and combines those assets from the whole portfolio of assets which have common characteristics),

- founding an SPV by either the originator or the financial institution which handles the process (ultimately, however, the SPV has to be independent from the originator in terms of its capital, legal status and personnel because the SPV needs to be characterized by bankruptcy remoteness, which means

R. Łopiński, M. Mikołajczyk, ABC Sekurytyzacji, [in:] Sekurytyzacja aktywów ze szczególnym uwzględnieniem wierzytelności hipotecznych - praktyczne doświadczenia w wybranych krajach europejskich, Stanach Zjednoczonych, Kanadzie i Polsce, "Zeszyt Hipoteczny" no. 16, Warsaw 2003, p. 14. Vide: S. Gudkova, Sekurytyzacja należności kredytowych banków, Warsaw 2002, p. 23-53. Similarly: S. Antkiewicz, Rola banków w procesie sekurytyzacji w świetle obowiązujących i planowanych przepisów prawnych, "Biuletyn Bankowy" 2006, no. 6, p. 85-86; M. Rudnicki, Wykorzystanie sekurytyzacji przez jednostki samorządu terytorialnego w pozyskiwaniu środków finansowych na inwestycje, "Finanse Komunalne" 2006, no. 1-2, p. 5. 
Securitization as an Instrument of Administration of Territorial Self-Government...

that its assets are secured against potential claims from the originator's creditors $\left.^{21}\right)$,

- selling claims to the SPV through transferring of claims or by the use of subparticipation or novation ${ }^{22}$,

- issuing securities by the SPV to discharge its obligations towards the originator for the purchased assets,

- rating the securities issued by the SPV,

- selling the issued securities to investors and transferring the means acquired in this way by the SPV to the originator as a payment for the assets purchased (at this stage the SPV may charge a commission for its service),

- re-purchasing the issued securities at the moment of their maturity with the means acquired from the originator.

It should be underlined that in order to limit the credit risk of the securities issued in a securitization the assets being securitized have to guarantee financial revenues in the future and enable to determine precisely the amount of these revenues. However, because of the fact that assets of such qualities are hard to achieve in practice, it is accepted that the assets selected for securitization should have a specified schedule of cash-flow, a low risk of repayment failure to assure investors that their claims shall be discharged, as well as an adequate unit value to achieve a diverse portfolio of claims (this is to assure that despite the failure to repay debts as stated in the schedule, in total the cash-flows shall be regular and of appropriate amount). What is more, the assets should be homogeneous in terms of type in case of securing the same series of securities issued, for instance arrears of taxes or obligations of national health service institutions being in debt, in which cases, however, certain diversity in a particular group of claims is advisable in order to decrease the influence of the particular assets' characteristics on the total cash-flows (e.g. demographic or regional diversity $)^{23}$.

21 S. Jóźwiak, P. Wiśniewski, Europejski rynek sekurytyzacji, “Bank” 2003, no. 9, p. 47.

22 M. Borek, Techniki sekurytyzacyjne w zarządzaniu bilansem banku, "Bank" 2001, no. 2, p. 59; P. Jaroński, Zagadnienia prawne sekurytyzacji na tle dotychczasowych prób transakcji sekurytyzacyjnych, [in:] Sekurytyzacja aktywów ze szczególnym uwzględnieniem wierzytelności hipotecznych - praktyczne doświadczenia w wybranych krajach europejskich, Stanach Zjednoczonych, Kanadzie i Polsce, "Zeszyt Hipoteczny" no. 16, Warsaw 2003, p. 25.

R. Łopiński, M. Mikołajczyk, op. cit., p. 13; J. Koleśnik, M. Rewieński, op. cit., p. 82-83. 


\section{Securitization in Poland - legal conditions}

In Poland securitization is regulated by the EU regulations and two acts, i.e. the Banking Law Act of 29 August, $1997^{24}$ and the Investment Funds Act of 27 May, $2004^{25}$. The regulation of securitization included in the Investment Funds Act does not sufficiently cover problems associated with securitization ${ }^{26}$. At present, it is the sole source of laws which provides legal definitions of 'pool of exposures, ' 'originator of securitization,' and 'securitized claims'. Article 4 Subparagraphs 25-27 of the Banking Law Act refers to the Investment Funds Act for definitions of 'investment fund management company,' 'securitization fund,' and 'sub-participation contract'.

For territorial self-government units, the regulation included in the Investment Funds Act is of more importance. As defined in Article 2 Subparagraph 31 of the Investment Funds Act, 'the originator of securitization' is either a territorial self-government unit, or a union of territorial self-government units, or a subject engaged in business activity, which either sell the pool of claims to the securitization fund or commit themselves to transfer to the securitization fund all the benefits acquired from a particular pool of claims. This means that territorial self-government units, a union of such units or e.g. municipal companies, as stated in the Municipal Management Act of 20 December, $1996^{27}$ can become originators of securitization.

During the work of the Sejm of the fourth term of office, a parliamentary bill draft of securitization was prepared ${ }^{28}$. The work, however, was not completed before the end of term of office. The reason for the suspension of the work was a lack of agreement concerning the solution to the problem of the enforcement clause for the issuer's enforcement titles ${ }^{29}$. It seems, however, that owing to the importance of the problem, the bill draft should return to the $\mathrm{Sejm}^{30}$.

\footnotetext{
24 Uniform text Journal of Laws - Dz. U. of 2002 No. 72, item 665 with amendments.

25 Journal of Laws - Dz. U. No. 146, item 1546 with amendments.

26 More about problems and perspectives of the development of securitization funds: R. Janiak, Długami handlowanie, "Bank" 2005, no. 9, p. 57-58. More about principles of carrying out securitization based on securitization funds and about the types of securitization funds: M. Barowicz, Powtórka z sekurytyzacji, "Bank" 2005, no. 11, p. 44-46; A. Zwolińska-Doboszyńska, Sekurytyzacja wierzytelności z udziałem funduszy sekurytyzacyjnych na tle innych uregulowań dotyczących sekurytyzacji, "Przegląd Prawa Handlowego" 2005, no. 2, p. 17-25; M. Rudnicki, op. cit., p. 8-14.

27 Journal of Laws - Dz. U. of 1997 No. 9, item 43 with amendments.

28 The bill draft of the Act on Securitization (parliamentary paper no. 2080, the Sejm of the fourth term of office).

29 P. Jaroński, Gdzie jesteś sekurytyzacjo?, "Bank” 2005, no. 2, p. 49.

30 More about the bill draft of securitization: M. Rudnicki, op. cit., p. 14-15.
} 


\section{Securitization as an instrument of the financial policy of territorial self-government units}

It needs to be clearly stated that currently banks are the greatest beneficiaries of securitization. Owing to the securitization of assets, they can increase their incomes from the credit portfolio by altering it, as well as acquire financial means for further credit activity ${ }^{31}$. However, in the specialist literature the problem of securitization carried out by territorial self-government units is being raised more and more frequently ${ }^{32}$. Unfortunately, the discussions on the problem are often too general. Nevertheless, it seems that in the theory of management there are no objections to this modern instrument of financial engineering to be used by units of the public finances sector in Poland including units of the self-government public finances subsector. In this field Poland should learn from the experience of American cities and states $^{33}$.

Securitization as a source of off-balance financing may facilitate the activity of wealthier territorial self-government units whose capability of debt handling is at a higher level than the one defined in Articles 169-170 of the Public Finance Act. Applying securitization by self-governments would enable to pass over the limits specified in the articles mentioned ${ }^{34}$.

The means acquired in a securitization whose originator is a territorial selfgovernment unit, as defined in Article 5 Section 1 Subparagraph 5 of the Public Finance Act, should be qualified as the public means which are the incomes of the

31 M. Borek, Techniki sekurytyzacyjne w zarządzaniu bilansem banku, "Bank" 2001, no. 2, p. 54.

32 B. Filipiak, Nowe instrumenty finansowe w zarządzaniu finansami, [in:] M. Dylewski, B. Filipiak, M. GorzałczyńskaKoczkodaj, Finanse samorządowe..., p. 200; B. Półtorak, Sekurytyzacja finansowych aktywów samorządowych, [in:] Perspektywy współpracy banku z samorządem terytorialnym w Polsce, edited by D. Korenik, Wroclaw 2005, p. 158-161; I. Kidacka, Finanse zintegrowane. Sekurytyzacja, struktury finansowe, Warsaw 2006, p. 306308; M. Poniatowicz, Obligacje przychodowe i sekurytyzacyjne jako innowacyjne instrumenty na polskim rynku komunalnych papierów wartościowych, "Finanse Komunalne" 2005, no. 3, p. 20-29.

33 I. Kidacka, op. cit., 148-149.

34 The problem was recognized in the bill draft of the Public Finance Act (parliamentary paper no. 1912, the Sejm of the fifth term of office) which was prepared by the cabinet of Prime Minister Jarosław Kaczyński. In Article 174 of the bill draft of the Public Finance Act, a new ratio limiting the repayment of territorial self-government units' obligations was formulated. This ratio shall be individually determined for each territorial self-government units. "On the one hand, the new ratio abolishes the currently binding limits for the territorial self-government units with high potential for development for which contracting even substantial financial obligations may be an instrument of a safe development policy. On the other hand, it imposes some discipline on the units whose excessive financial obligations require caution in contracting new credits and loans. It is estimated that the annual value of the obligations to be repaid and the related services compared with the projected incomes can not excess the ratio based on the arithmetical average for the previous three years calculated from the relation of the current incomes enlarged by the revenues from sales of property and reduced by the current expenditures having excluded the interest to the incomes in total. This ratio is calculated on the basis of reports from the previous three years and presents the real capability of the obligations repayment by a particular territorial self-government unit." (the explanatory statement to the bill draft of the Public Finance Act, p. 17) There is high likelihood that Donald Tusk's cabinet shall accept this solution for their bill draft of the Public Finance Act (at the time the article was being written the bill draft had not yet been presented.) However, even if the rules for calculating the limits of the obligations repayment by territorial self-government units were to be changed, securitization may still be an attractive instrument for gaining external capital. 
public finances sector's units from other sources. They shall not be incomes from other financial operations (Article 5 Section 1 Subparagraph 4(a) of the Public Finance Act). The reason for this is that it is not the territorial self-government unit that shall acquire the means on financial markets; the SPV is to do this.

The means acquired by territorial self-government units in securitizations can be utilized by territorial self-government units in a number of ways: to cover a temporary budget deficit arising over the budget year, to finance the projected budget deficit, or to repay the obligations previously contracted on account of securities to be issued as well as their loans and credits, providing that either the new sources of financing should be cheaper or fulfilling the limits specified in Articles 169-170 of the Public Finance Act should be endangered.

In the specialist literature it is suggested that by the use of securitization techniques it is possible for national health service institutions to have their debts written off ${ }^{35}$. This process shall be based on taking over their debts by voivodship and poviat self-governments which are founding bodies for public hospitals. Taking over the debts shall occur in the form of loan granting to hospitals by self-governments. Then the obligations resulting from the granted loans shall be transferred onto the SPV which, pursuant to these assets, issues long-term securities (e.g. for 7 years with a prolongation option). The hospitals' repayments of debts shall be forwarded by self-governments to the SPV in order to pay off the obligations towards the investors. At present, however, such a task seems impossible to be carried out. Apart from the lack of appropriate legal solutions for securitization, it is doubtful whether hospitals, which are continually increasing their indebtedness, would be able to begin to handle the repayment of their debts within a few years. In case of a negative answer to this question, financial collapse of poviat and voivodship governments whose budgets even at present are relatively low would have to be taken into account.

The specialist literature also suggests that securitization could be applied in financing costly undertakings in the field of environmental protection and proecological investments ${ }^{36}$.

The catalogues of tasks which can be financed with means acquired from securitization are defined in the acts regulating the activity of territorial selfgovernments of particular levels in Poland ${ }^{37}$. It appears that the tasks financed should have the nature of investment rather than be of the operational character, considering the scale of the securitization process (it is accepted that the profitability

35 M. Poniatowicz, op. cit., p. 26-29.

36 M. Rudnicki, op. cit., p. 7, 13.

37 The Act of 8 March 1990 on Local Self-Government (uniform text Journal of Laws - Dz. U. of 2001 No. 142 , item 1591 with amendments), the Act of 5 June 1998 on Poviat Self-Government (uniform text Journal of Laws - Dz. U. of 2001 No.142, item 1592 with amendments), the Act of 5 June 1998 on Voivodeship Self-Government (uniform text Journal of Laws - Dz. U. of 2001 No. 142, item 1590 with amendments). 
Securitization as an Instrument of Administration of Territorial Self-Government...

of a securitization scheme is assured by issuing of securities worth about PLN 50 million $^{38}$ ). Securitization transactions may be used by self-governments to build or extend infrastructure such as roads, tram lines, or laying of pipes, sewers and power lines. Such investments should raise the standard of living and attractiveness of the territorial self-government units investing. This may result in an increase in the budget incomes and facilitate the handling of the securitization applied.

All the assets fulfilling the criteria mentioned in this article can be securitized. This is why it appears that in securitization whose originator is a territorial selfgovernment unit the securitization may cover all the incomes of territorial selfgovernment units determined in the Local Government Revenue Act of 13 November, $2003^{39}$, providing that the projected cash-flow over a definite period of time and of a specified amount can be determined. Therefore, incomes such as inheritances, legacies and donations to gminas, poviats and voivodships can not be securitized. Moreover, a detailed legal analysis should be performed to determine options for securitization of the proceeds from local taxes or for securitization of shares in income taxes. There is no doubt, however, that a gmina can have the tax arrears securitized.

Finally, securitization can be carried out on, e.g., future incomes of municipal companies.

\section{The advantages and disadvantages of securitizations carried out by territorial self-government units}

The basic advantage of securitization is the possibility of exchanging the dues scheduled over time for single incomes acquired from the issuing of securities. Owing to such operations, the originator of securitization (e.g. a territorial selfgovernment unit) gains a direct influx of money and divests the risk associated with the claims sold. What is more, as a result of this kind of transaction the originator is secured in case the SPV is not capable of paying off the issued securities with the claims transferred ${ }^{40}$. In addition, securitization helps territorial self-government unit to achieve the effect of their debt structure adjustment, to accelerate the realization of certain projects, to improve liquidity ratio owing to the liquidation of low liquidity ratio assets and, finally, to diversify sources of financing for their activity by forwarding offers to purchase securities to many investors.

\footnotetext{
$38 \quad$ R. Łopiński, M. Mikołajczyk, op. cit., p. 19.

39 The Act of 13 November 2003 on Local Government Revenue (uniform text Journal of Laws - Dz. U. of 2008 No. 88, item 539).

40 K. Haładyj, Mechanizmy zbywania wierzytelności bankowych, “Transformacje Prawa Prywatnego” 2006, no. 1, p. 37.
} 
Problems with applying securitization techniques by territorial self-government units may arise due to unfavorable legal conditions. Despite the authority to apply securitization by territorial self-government units included in the Investment Funds Act, the reality shows that self-governments do not use this instrument. The reason for this situation is complex. Apart from the unfavorable legal conditions, it needs to be underlined that self-government officials possess a low level of the specialist knowledge of finances, which results in the ignorance of the modern financial instruments facilitating a rational administration of self-governments' assets.

Presumably, securitization due to its high profit threshold shall rather be used by larger and wealthier territorial self-government units which additionally shall be able to make use of the experience of academic circles active in their areas. Small gminas and poviats shall not take the risk of applying an unknown financial instrument, even in the multi-sellers program whereby a number of originators may securitize homogeneous assets in one pool (e.g. the securitization of tax arrears by twenty gminas).

Therefore, a return to the concept of passing the act on securitization should be proposed. The act should resolve basic problems connected with carrying out securitizations. Moreover, the act should determine the principles for originating securitizations by self-governments as well as clearly define the catalogue of assets which can be securitized by self-governments. Finally, it should be suggested that the tax regulations should be changed so that they introduce the tax neutrality of securitization. In case of financing public tasks by the use of securitization, the Polish tax system should even perform a stimulating function for a dynamic development of securitization transactions ${ }^{41}$. 


\section{Streszczenie}

Celem niniejszego artykułu jest przedstawienie możliwości zastosowania instytucji sekutyryzacji przez jednostki samorządu terytorialnego dla efektywnego zarządzania środkami budżetowymi. Dokonana analiza opiera się na regulacjach ustawy o finansach publicznych z 2005 r. Autor próbuje zaklasyfikować środki nabyte w ramach sekularyzacji do jednej z kategorii środków publicznych wymienionych $\mathrm{w}$ art. 5 ustawy. Ponadto rozważa zastosowanie sekutyryzacji w różnych jednostkach samorządu terytorialnego stosownie do ustawy o dochodach jednostek samorządu terytorialnego z $2003 \mathrm{r}$. 